\title{
Research on Marketing Strategy Innovation of Xi'an Small and Medium-sized Private Enterprises in the Era of New Media and Artificial Intelligence
}

\author{
Chunli Huang \\ Xi'an FANYI University \\ $\mathrm{Xi}$ 'an, China
}

\begin{abstract}
With the rapid development of new media and artificial intelligence, marketing innovation is imperative for enterprises. The aim of this study is to provide some suggestions and references to the marketing innovation of private SMEs in Xi'an. The research methods of this study are the interview method, the SWOT analysis method, and BCG matrix. This paper discusses the impact of new media and artificial intelligence on enterprise marketing, analyzes the current situation and existing problems of marketing of private SMEs in Xi'an. Finally, a new framework for the marketing strategy innovation of private SMEs in Xi'an is proposed.
\end{abstract}

Keywords—new media; artificial intelligence; marketing; innovation; private enterprises

\section{INTRODUCTION}

China has entered the era of new media and artificial intelligence. In 2018, China's Internet users reached 829 million, including 817 million mobile Internet users, and the Internet penetration rate was $59.60 \%$. With the development of digital and information technology, various new media, such as mobile media, IPTV, blog, micro-blog, APP, LBS and so on, appear continuously. New media has the characteristics of participation, openness, communication, community and connectivity. They are gradually changing media usage and consumption patterns of consumers, and they also permeate all aspects of enterprise marketing fundamentally.

With the development of artificial intelligence, the integration of artificial intelligence and traditional industry is becoming an important driving force for the transformation and upgrading of China's economy. In the congratulatory letter to the Tianjin World Intelligence Conference in 2019, general secretary $\mathrm{Xi}$ Jinping pointed out that China will pay more attention to innovation and development, take the new generation of artificial intelligence as the driving force to promote the leapfrogging development of science and technology, optimize and upgrade the industry, and the overall jump in productive forces, and strive to achieve high-quality development. According to the report on new generation artificial intelligence science and technology industry development, the development of artificial intelligence is demand-led and is widely used in many areas, such as, transportation, financial science and technology, intelligent manufacturing, new retail and security, etc. Intelligent economy in China will usher in a golden period of

This research was supported by Xi'an Social Science Foundation Project "Research on Marketing Strategy Innovation of Xi'an Small and Mediumsized Private Enterprises in New Media Era" under Grant 16XF07. development.

With the increasing popularity of new media and the upgrading of artificial intelligence technology, the marketing mode of traditional media is unable to meet the needs of customers, and the marketing reform is increasingly imperative. It is crucial for small and medium-sized private enterprises to combine new media and artificial intelligence technology to carry out effective marketing strategy innovation, further to cater to the needs of consumers, efficiently achieve marketing goals, and improve enterprise efficiency and competitiveness.

\section{The Meaning of New Media, New Media MARKETING AND ARTIFICIAL INTELLIGENCE}

New media refers to the media which disseminate digital text, sound and image information based on computer information processing technology, by various modern communication means, such as, broadband, wireless, cable, satellite networks, etc. [2]. New media are unlikely to prove qualitatively different from the old ones. New media are the platforms for sharing information and social activities of users, whose core feature is interactive. The main content of new media is UGC (user production content), and the key structure of new media is the relationship network.

New media marketing refers to the whole process in which enterprises or individuals make full use of the functions and characteristics of the new media platform under the guidance of new media thinking, develop personalized products and services according to the needs of the target customers, adopt new media marketing methods, and carry out new media marketing activities based on the accurate positioning of the target customers. At present, the main carriers of new media marketing consist of new media of Internet, new media of mobile phone, new TV media and outdoor new media. The common methods used in new media marketing include viral marketing, community marketing, database marketing, reverse communication, experiential marketing, word of mouth marketing, precision marketing, event marketing, etc.

The phrase "artificial intelligence" was first proposed at the Dartmouth Institute in 1956. Artificial intelligence is a new technical science which is used to simulate and extend human intelligence. Artificial intelligence holds dominant position in games, natural language processing, visual systems, speech recognition, handwritten recognition, intelligent robots and 
other fields, such as a machine translation system, a manmachine conversation system, and the like.

\section{ThE INFLUENCE OF NEW MEDIA AND ARTIFICIAL}

INTELLIGENCE ON THE MARKETING OF PRIVATE SMALL AND

\section{MEDIUM-SIZED ENTERPRISES}

New media based on digital technology and network technology and the rapidly developing artificial intelligence technology have changed the competitive thinking of marketing for private small and medium-sized enterprises, and the traditional marketing strategy and the strategy based on offline marketing have become inadequate. Nowadays, new media and artificial intelligence technology integration is the trend. The era of New Media is the era of the attention economy. The consumers' reading of the promotion information is changed from the static immersion reading mode to the interactive reading mode, and if the online reading content does not come out in three seconds, the consumers will choose to jump out [5]. The new media era is also the era of mobile scene reading. The rapid development of mobile Internet makes enterprise marketing change to mobile marketing rapidly. The marketing of two-dimension code, mobile advertisement design, App marketing and other mobile terminal marketing are becoming popular. The era of new media is an era of participation. After purchasing the goods, consumers can print on the micro-blog and the WeChat, and the other users can interact in such a way as to pay attention to, forward the friend circle of WeChat, and so on. For the products with the user community's high praise, the products were invisibly publicized, and the enterprises also realize virustype marketing. The era of new media is VUCA (Volatility, Uncertainty, Complexity, Ambiguity) era, the demand of consumers is full of variability, impermanence, complexity and fuzziness, and the marketing of private small and mediumsized enterprises must keep pace with the times and meet the needs of users. Meanwhile, the new media era also brings the opportunity of digital marketing and diversified value to the development of private small and medium-sized enterprises. In the new media age, the Internet and mobile end have become one of the important reading carriers.

The development of artificial intelligence has brought many opportunities and convenience to enterprise marketing. For example, many small and medium-sized enterprises have never advertised, they not only have no data accumulation, but also lack of marketing popularization experience. At this time, we can help small and medium-sized enterprises to find the target customers more accurately by the use of artificial intelligence algorithm knowledge. After finding the accurate target customers, the enterprises need to communicate with users, further integrate creativity and optimize their products or services.

\section{THE CURRENT SITUATION \& PROBLEMS OF THE MARKETING OF PRIVATE SMES IN XI'AN}

As of January 2019, there were 1.5 million market participants in Xi'an, which include 1.4613 million private enterprises, and the tertiary industry has become the largest industrial sector in Xi'an. The private small and medium-sized enterprises in Xi'an play a more and more important role in stimulating the economic growth of Xi'an.

With the vigorous development of new media and artificial intelligence, more and more small and medium-sized enterprises in Xi'an have recognized that the marketing thinking must be changed. Meanwhile, these new technologies drive enterprises to innovate constantly, which include artificial intelligence, AR, cloud computing, the Internet of things, etc. However, there are still some small and medium-sized enterprises in Xi'an who can't keep up with the requirements of the times, and their marketing strategies are lagging behind. How to carry out the new marketing strategy of new media and artificial intelligence thinking is an important matter to SMEs.

Under specific circumstances, different industries and enterprises have different marketing strategies. There are some common marketing strategies including portal marketing, WeChat marketing, micro-blog marketing, micro store marketing, online video marketing, search engine marketing, E-mail marketing, BBS marketing, IM marketing, mobile phone new media marketing, etc.[4]. For example, some marketing methods are usually used to improve marketing effectiveness by the traditional publishing enterprises, which include the construction of publishing house website, direct sales of electronic publications, joining electronic newspapers sales platform and other ways. Cosmetics industrial enterprises set up official direct micro-stores and online shops to sell their products.

The new media marketing has brought great changes to the marketing of some private small and medium-sized enterprises in Xi'an. The changes are as follows. Firstly, it reduces the marketing cost and accelerates information transmission. Secondly, new media marketing extends the creative field of marketing. Thirdly, new media marketing can accurately position the target market, meet customers' personalized demands, and effectively deliver comprehensive, scientific solutions. Fourthly, the new media is characterized by timeliness and sharing, which can significantly improve marketing results of enterprises by the use of interactive marketing, topic marketing, viral marketing and other ways.

However, in the new media and artificial intelligence era, there are still many existing problems of marketing for private small and medium-sized enterprises in Xi'an.

Firstly, most private small and medium-sized enterprises in Xi'an lack of high-end technology, in the era of artificial intelligence, they have fallen far short of effective marketing. Secondly, in the new media era, some small and medium-sized private enterprises in Xi'an lack scientific and effective planning in marketing management. Some private SMEs in Xi'an pay too much attention to the income of products or services, and ignore the cultivation of core competence. Thirdly, lack of high-quality and compound marketing talents. In the new media and artificial intelligence era, enterprises need a large number of high-quality and complex marketing talents in the construction and development. Because of the low visibility and the imperfect welfare treatment mechanism, it is difficult for private small and medium enterprises to attract excellent marketing talents, and the turnover rate of existing marketing talents is also high. Fourthly, the innovation ability 
When carrying out new media marketing, enterprises can of new media and AI marketing is weak. In the new media and artificial intelligence era, the marketing environment of private SMEs in Xi'an has changed greatly. The spending patterns and media usage habits of consumers are changing. Some small and medium-sized private enterprises are also eager to make marketing innovation. However, due to the lack of mature experience in new media and artificial intelligence marketing, the enterprises can only continue to explore marketing innovation, the speed of innovation is slow, and the overall innovation capability is weak.

\section{SUGgestions}

Nowadays, new media and artificial intelligence technology infiltrate social life more extensively. How to reach the marketing goals through new media and artificial intelligence technology, and how to realize the transformation and upgrading of the industry are the urgent problems that enterprises must consider seriously. Before carrying out marketing, private small and medium-sized enterprises should take a full range of systematic thinking on the marketing forms and profit models of their products or services, set specific marketing goals and make decisions from the following four steps.

\section{A. To understand marketing environment and customer demand, and carry out STP strategy}

First of all, enterprises should be familiar with the marketing environment, and think about the needs of customers. On the basis of analysis and prediction of the overall market, accurate market segmentation and market positioning are carried out.

\section{B. The choice of marketing media and marketing channels}

Private SMEs should choose the marketing media and marketing channels based on scientific decisions.

\section{Selecting suitable marketing strategies in the light of their own resource size, technical ability and operation capability.}

\section{1) AI marketing}

Artificial intelligence can simplify the marketing task and enrich the interaction with customers. Such as, the intelligent chat robots can be used for real-time and close interaction with the customers via the internet. AI robots can also have access to the entire Internet data, information and search history, making it more efficient than human behavior.

\section{2) New media marketing}

New media marketing methods mainly include word-ofmouth marketing, hungry marketing, knowledge marketing, emotional marketing, soft text marketing, event marketing, interactive marketing and member marketing [6].Small and medium-sized enterprises can make full use of the characteristics of "fast, accurate and ruthless" information dissemination on the new media platform, run through the whole process of new media marketing activities by means of event marketing, word-of-mouth marketing, interactive marketing and so on, and use Internet thinking, cross-border thinking, big data thinking, shared economic thinking and other new media marketing thinking to innovate the marketing process. choose the following strategies of new media marketing.

\section{a) Search engine marketing}

When advertising on search engines, first of all, enterprises should choose appropriate search engines according to the budget, the characteristics of the customer groups, and different search engine features.

When items are on sale, the products or services can be registered on the classified catalogues of some search engines (such as Sina, Sohu, NetEase and other portals). Enterprises can increase the chances that their own site will be searched by exchanging links on other websites. The setting of keywords can be based on the characteristics of products or business and some current social hot words. When selecting keywords, enterprises should mainly consider two factors, which include keyword popularity and keyword competitiveness. Keywords should not be too broad, too broad keywords own high popularity, fierce competition and high cost. The customer conversion rate is usually low.

\section{b) Portal marketing}

The enterprises carry out the marketing of products or services through their own portal websites [3].The website should be simple, practical and effective. The website interface style should match with the enterprise's self-image and proprietary products. Enterprises can use the necessary network marketing tools such as query tools, statistical tools to advance the implementation effect of network marketing. Of course, the marketing can also be carried out by means of online advertising or viral marketing application tools on other portal website. Enterprises can put in brand site advertising to improve brand awareness on comprehensive portal website, and put in promotional advertisements with higher matching with the customers on vertical portal website. At present, most of the integrated portals have developed forums, micro-blog, video and other application tools conducive to viral marketing. Enterprises can make full use of these platforms of integrated portals to create "viruses" that are beneficial to enterprises, and realize the spread of "viruses", in order to promote websites and brands.

\section{c) Social media marketing}

Social media is a new kind of online media which gives users great participation space [1].It has the characteristics of participation, openness, communication, dialogue, community, connectivity and so on. Its most obvious characteristic is to give everyone the ability to create and disseminate content. According to the characteristics of products or services, investment size and so on, the small and medium-sized private enterprises may consider one or more combinations of marketing methods, such as blog marketing, micro-blog marketing, WeChat marketing, SNS marketing, and forum marketing, etc. Before carrying out blog marketing, enterprises should select the appropriate third party blog platform or build their own blog platforms. The selected blog platform should have higher visibility and weight advantages of search engines, which is conducive to the promotion of enterprise products or services. While carrying out micro-blog marketing, enterprises should first realize the interests of fans and pay attention to the accurate positioning of target customers. Secondly, we should 
write micro-blog contents carefully and attach importance to data analysis, attract valuable fans, and capture commercial value from micro-blog fans. Thirdly, Enterprises should pay attention to differentiated micro-blog marketing, shape the personalized features of their own micro-blogs, and continue to accumulate target fans. Enterprises should seriously choose effective marketing strategies, such as interactive marketing, emotional marketing, integrated marketing communication, high-quality content, opinion leaders, multi-account matrix and other strategies.

Interactive marketing strategy means that enterprises use the right way on micro-blog platform to establish the benign interaction between enterprises and consumers, find out the balance of interests between the two, so as to achieve the purpose of win-win. Finally, micro-blog marketing should have a professional operation team. Companies may also choose the right SNS platforms for web advertising and implantable marketing based on the nature and characteristics of their products or services, or achieve viral marketing through the SNS platforms.

\section{d) Network video marketing}

Nowadays, there are five modes of network video marketing, which are network video patch advertising, network video virus marketing, microfilm marketing, network selfmade drama marketing and network self-made program marketing. First of all, enterprises should know whether their products or services are suitable for network video marketing. In 2019, Internet users in China show a trend of being younger. Therefore, when carrying out network video marketing, advertisers must consider the actual situation of Internet users in China, identify the target customers, and select appropriate network video marketing strategy that meets the customers' needs. Online video patch advertising refers to the videoindependent advertising content inserted at the beginning or the end of video, the length of which is similar to that of traditional TV advertising. The main forms of online video patch advertising are traditional pre-patches, large occlusion patch and the background patch. The broadcast form of large blocking patch and background patch advertisement is more sensory impact, and it is also more interactive than the traditional pre-patch. The marketing mode of micro film has the characteristics of soft publicity, low cost, convenient communication, etc. At present, the mainstream marketing mode of micro film mainly includes three ways: sponsorship, implantation and brand content. Network homemade play marketing means that the enterprise should implant product or brand in the plot of the play in order to promote.

\section{The construction of marketing effect and innovation ability evaluation system}

Enterprises should build a scientific and effective evaluation system of marketing effect and innovation ability. The effective evaluation system will enable enterprises to understand their own weaknesses in the construction and development and guide the enterprises to strengthen the marketing management and improve their core competitiveness. The evaluation elements should be specific, measurable, achievable, and time specific.

\section{CONCLUSION}

In the era of new media and artificial intelligence, marketing reform is imperative. How to use new media and artificial intelligence technology scientifically and efficiently, implement effective marketing strategies and tactics, obtain and analyze customer data, and ultimately increase the sales performance, has become a "roadblock" of many private SMEs. Private SMEs should establish new media and artificial intelligence marketing awareness, use scientific and effective marketing strategies to improve sales performance and competitiveness.

Firstly, private enterprises should analyze the needs of customers and competitiveness of their products or services, and carry out accurate segmenting, targeting and positioning. Secondly, Private SMEs should choose the appropriate marketing media and marketing channels. According to the characteristics of different media, private enterprises can consider the use and integration of old and new media. Thirdly, the private enterprises should define the appropriate marketing strategy based on the analysis of their own resource size, technical ability and operation capability. When choosing AI marketing or new media marketing, enterprises must consider the impact and effect of marketing. Finally, the evaluation system of marketing effect and innovation ability should be built.

\section{ACKNOWLEDGMENT}

This research was supported by Xi'an Social Science Foundation Project "Research on Marketing Strategy Innovation of Xi'an Small and Medium-sized Private Enterprises in New Media Era” under Grant 16XF07.

\section{REFERENCES}

[1] Reto Felix and Philipp A.Rauschnabel, "Elements of strategic social media marketing: A holistic framework,” Journal of Business Research, vol.70, 2017, pp.118-126.

[2] Koteshwar Chirumalla and Pejvak Oghazi, "Social media engagement strategy: Investigation of marketing and R\&D interfaces in manufacturing industry," Industrial Marketing Management, vol.74, 2017, pp.138-149.

[3] Randall A. Lewis and David H. Reiley, “Online ads and offline sales: Measuring the effect of retail advertising via a controlled experiment on Yahoo,” Quantitative Marketing and Economics, 2014.

[4] Lovett, Mitchell J, Renana Peres, and Ron Shachar, "On brands and word of mouth,” Journal of Marketing, 2013.

[5] Thomas, Direct Marketing in Practice, BKS Press, 2011, pp.6-8.

[6] Rong Cuihong and Yin Jie, "Characteristics and trends of new media marketing communication,” Journal of Wuhan University of Technology (Social Science Edition), vol.5, 2018, pp.49-53.(In Chinese) 